\title{
Strength, Carbonation Resistance, and Chloride-Ion Penetrability of Cement Mortars Containing Catechol-Functionalized Chitosan Polymer
}

\author{
Se-Jin Choi ${ }^{1}$, , Sung-Ho Bae ${ }^{1}$, Jae-In Lee ${ }^{1}$, Eun-Ji Bang ${ }^{2}$ and Haye-Min Ko ${ }^{3, *(\mathbb{C}}$ \\ 1 Department of Architectural Engineering, Wonkwang University, Iksan 54538, Korea; \\ csj2378@wku.ac.kr (S.-J.C.); caos1344@naver.com (S.-H.B.); wodls103@naver.com (J.-I.L.) \\ 2 Department of Chemistry, Wonkwang University, Iksan 54538, Korea; dmswlal1@naver.com \\ 3 Department of Chemistry, Wonkwang Institute of Material Science and Technology, Wonkwang University, \\ Iksan 54538, Korea \\ * $\quad$ Correspondence: hayeminko@wku.ac.kr; Tel.: +82-63-850-6789
}

Citation: Choi, S.-J.; Bae, S.-H.; Lee, J.-I.; Bang, E.-J.; Ko, H.-M. Strength, Carbonation Resistance, and Chloride-Ion Penetrability of Cement Mortars Containing CatecholFunctionalized Chitosan Polymer. Materials 2021, 14, 6395. https:// doi.org/10.3390/ma14216395

Academic Editor: Didier Snoeck

Received: 22 September 2021

Accepted: 21 October 2021

Published: 25 October 2021

Publisher's Note: MDPI stays neutral with regard to jurisdictional claims in published maps and institutional affiliations.

Copyright: (c) 2021 by the authors. Licensee MDPI, Basel, Switzerland. This article is an open access article distributed under the terms and conditions of the Creative Commons Attribution (CC BY) license (https:// creativecommons.org/licenses/by/ $4.0 /)$.

\begin{abstract}
There have been numerous recent studies on improving the mechanical properties and durability of cement composites by mixing them with functional polymers. However, research into applying modified biopolymer such as catechol-functionalized chitosan to cement mortar or concrete is rare to the best of our knowledge. In this study, catechol-functionalized chitosan (Cat-Chit), a well-known bioinspired polymer that imitates the basic structures and functions of living organisms and biological materials in nature, was synthesized and combined with cement mortar in various proportions. The compressive strength, tensile strength, drying shrinkage, accelerated carbonation depth, and chloride-ion penetrability of these mixes were then evaluated. In the ultraviolet-visible spectra, a maximum absorption peak appeared at $280 \mathrm{~nm}$, corresponding to catechol conjugation. The sample containing 7.5\% Cat-Chit polymer in water (CPW) exhibited the highest compressive strength, and its 28-day compressive strength was $\sim 20.2 \%$ higher than that of a control sample with no added polymer. The tensile strength of the samples containing $5 \%$ or more CPW was $\sim 2.3-11.5 \%$ higher than that of the control sample. Additionally, all the Cat-Chit polymer mixtures exhibited lower carbonation depths than compared to the control sample. The total charge passing through the samples decreased as the amount of CPW increased. Thus, incorporating this polymer effectively improved the mechanical properties, carbonation resistance, and chloride-ion penetration resistance of cement mortar.
\end{abstract}

Keywords: Cat-Chit polymer; cement mortar; compressive strength; carbonation depth; chloride-ion penetrability

\section{Introduction}

Concrete is a widely used material in the construction field for its many advantages, such as its low cost, excellent compressive strength, and high durability [1]. However, its tensile strength is low, and it is vulnerable to cracks due to various causes, such as shrinkage or chemical reactions. In addition, maintenance activities, such as repairing cracks, can be significantly costly [2]. Over the past decade, numerous studies have developed various functional admixtures (shrinkage-reducing agents, watertight admixtures, etc.), fiber reinforcements (e.g., Polyvinyl alcohol (PVA) fiber and amorphous metallic fiber), and polymer materials to overcome these problems in cement mortar or concrete [3-10].

Recently, various research studies have mixed functional polymers into cement composites in order to enhance the mechanical properties and durability of cement composites [11-19]. Jo et al. [11] examined the characteristics of polymer concrete using unsaturated polyester resins from recycled polyethylene terephthalate plastic waste and recycled concrete aggregate; they reported that the strength of polymer concrete increased as the 
resin content increased. Ferdous et al. [12] investigated the effect of the resin-to-filler ratio on the mechanical properties of epoxy-based polymer concrete, and they found that the resin-to-filler ratio significantly affects the spatial distribution of aggregates. Meanwhile, Azadmanesh et al. [13] used a polymer of styrene butadiene rubber and ethylene vinyl acetate to improve the mechanical properties of Engineered Cementitious Composites (ECC) using unoiled fibers. Their findings showed that the use of polymers can significantly improve the tensile and flexural strength properties of ECC. Mohesson et al. [14] characterized concrete mixed with alginate (a biopolymer), which increased both the compressive and tensile strengths of the concrete. In addition, Shanmugavel et al. [15] reported that adding biopolymers from cactus extract to cement paste increased both the viscosity and durability of the concrete.

However, in general, most studies employed conventional resin, epoxy, etc., as polymer additives in cement composites, but no studies have specifically focused on applying modified bioinspired polymers to cement mortar or concrete.

In this study, catechol-functionalized chitosan (Cat-Chit), a well-known bioinspired polymer that imitates the basic structures and functions of living organisms and biological materials in nature, was synthesized to examine its applicability in cement mortar. Chitosan, the most popular biopolymer, is obtained by the deacetylation of chitin, which is widely found in crustaceans. In recent decades, the applications of Cat-Chit in biomedicine have been well established, such as tissue adhesives [20] and drug delivery systems [21], because of its medical benefits as well as its low toxicity and biodegradability. However, its low solubility in aqueous solutions hindered its further advancement in this field [22-28]. In order to overcome this critical issue, chitosan-based derivatives have been synthesized via amide formation with 3,4-dihydroxyhydrocinnamic acid and amine [20,21,29-32]. The catechol group in the chitosan backbone increases not only its solubility but also its adhesion to tissues. Cat-Chit polymers (CCPs) have also been modified by using several nanoparticles $[33,34]$. These results have attracted significant attention to CCPs owing to its superior capability as a versatile material.

Therefore, in this study, we synthesized a catechol-functionalized chitosan polymer (CCP) and examined its applicability to cement mortar. To this end, we analyzed this CCP, and we evaluated mortar samples containing CCP in terms of their compressive strength, tensile strength, drying shrinkage, accelerated carbonation depth, and chlorideion penetrability.

\section{Materials and Experimental Methods}

\subsection{Materials}

In order to synthesize $\mathrm{CCP}$, Chitosan (medium molecular weight; degree of deacetylation: 75-85\%) and hydrocaffeic acid (HCA; 3-(3,4-dihydroxyphenyl)propionic acid) [35] were used in this study. In addition, we used 1-Ethyl-3-(3-dimethylaminopropyl)carbodiimide hydrochloride (EDC) and ethanol. All the chemicals were of analytical grade and were used without further purification. A Q-Grad 1 purification cartridge from Millipore water purification systems was used to obtain ultrapure water.

In addition, we used ASTM typeIordinary Portland cement with a specific gravity of 3.15 made by Asia Co. (Seoul, Korea). Table 1 lists its chemical composition. For fine aggregates, sand from the Namwon region with a specific gravity of 2.6 and a fineness modulus of 2.89 was used. Figure 1 shows the particle size distribution of the fine aggregate.

Table 1. Chemical composition of the cement used in this study.

\begin{tabular}{lcccccc}
\hline Components & $\mathrm{SiO}_{2}$ & $\mathrm{Al}_{\mathbf{2}} \mathbf{O}_{3}$ & $\mathrm{Fe}_{\mathbf{2}} \mathbf{O}_{3}$ & $\mathrm{CaO}$ & $\mathbf{M g O}$ & $\mathbf{K}_{\mathbf{2}} \mathbf{O}$ \\
\hline Ratio $(\%)$ & 17.43 & 6.50 & 3.57 & 64.40 & 2.55 & 1.17 \\
\hline
\end{tabular}




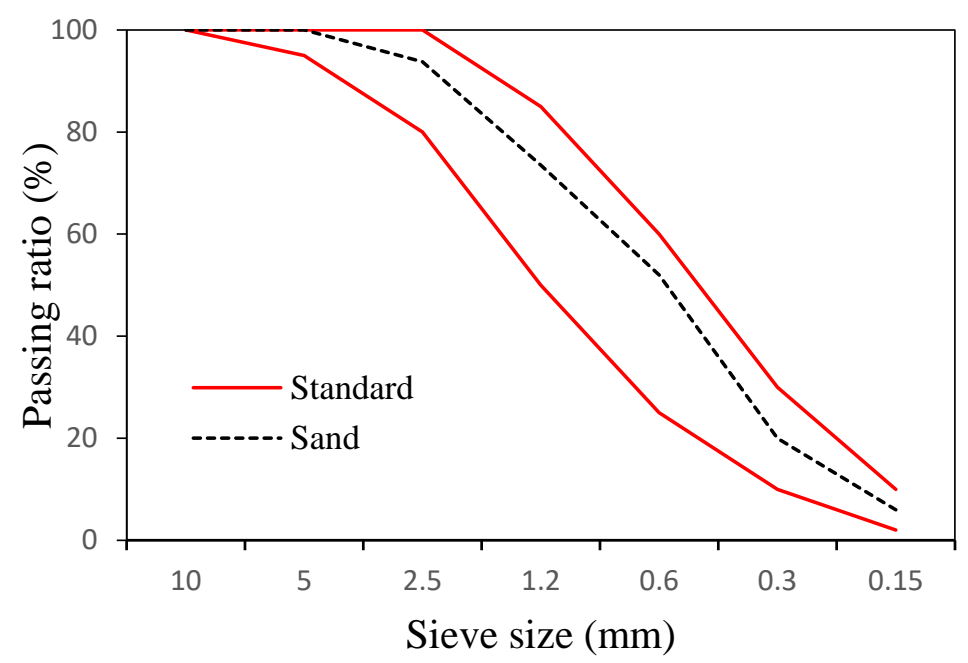

Figure 1. Particle size distribution of fine aggregates used in this study.

\subsection{Mix Proportions and Specimen Preparation}

Table 2 lists the mix proportions used in this study. The water-cement ratio (W/C) was fixed at $50 \%$, which is widely used for conventional concrete. A CCP solution, in which $500 \mathrm{mg}$ of CCP was dissolved in $1000 \mathrm{~mL}$ of water (hereinafter, CPW), was mixed at proportions of $0 \%, 2.5 \%, 5.0 \%, 7.5 \%$, and $10.0 \%$ of mixing water. For the sake of simplicity, samples are labeled with a suffix indicating the amount of CPW, e.g., CPW2.5 contained $2.5 \%$ CPW, as shown in Table 2. These CPW dosages correspond to $1.25 \%$ (CPW2.5) and to $5.0 \%$ (CPW10) of the cement weight.

Table 2. Samples and their mix proportions used in this study.

\begin{tabular}{|c|c|c|c|c|c|}
\hline Mix & $\begin{array}{l}\text { CPW } \\
(\%)\end{array}$ & $\begin{array}{l}\text { W/C } \\
(\%)\end{array}$ & $\begin{array}{c}\text { Water } \\
\left(\mathrm{kg} / \mathrm{m}^{3}\right)\end{array}$ & $\begin{array}{l}\text { Cement } \\
\left(\mathrm{kg} / \mathrm{m}^{3}\right)\end{array}$ & $\begin{array}{c}\text { Sand } \\
\left(\mathrm{kg} / \mathrm{m}^{3}\right)\end{array}$ \\
\hline Control & 0 & & & & \\
\hline CPW2.5 & 2.5 & & & & \\
\hline CPW5.0 & 5.0 & 50 & 170 & 340 & 739 \\
\hline CPW7.5 & 7.5 & & & & \\
\hline CPW10 & 10 & & & & \\
\hline
\end{tabular}

A mechanical mixer was used to mix the cement mortar. Then, cubic specimens with dimensions $50 \mathrm{~mm} \times 50 \mathrm{~mm} \times 50 \mathrm{~mm}$ were prepared via molding for compressive strength testing, and cylindrical specimens of dimensions $\varnothing 50 \mathrm{~mm} \times 100 \mathrm{~mm}$ were prepared for splittensile strength testing. Additionally, specimens of dimensions $40 \mathrm{~mm} \times 40 \mathrm{~mm} \times 160 \mathrm{~mm}$ were prepared for drying shrinkage and accelerated carbonation testing, and cylindrical specimens of dimensions of $\varnothing 100 \mathrm{~mm} \times 50 \mathrm{~mm}$ were prepared for the chloride ion penetration test.

Each specimen was demolded after $24 \mathrm{~h}$ and cured in water at $20^{\circ} \mathrm{C}$. The flow and compressive strength of the cement mortar mixes were measured according to the standard KS L 5105 [36], and the tensile strength was measured according to KS F 2423 [37]. The drying shrinkage of the samples was measured according to the standard KS F 2424 [38]. In the accelerated carbonation test, the carbonation depth was measured by using a phenolphthalein solution after the carbonation process in an accelerated carbonation chamber according to the standard KS F 2584 [39]. Additionally, the chloride-ion penetration test was performed according to ASTM C 1202 [40]. This test method involves monitoring the amount of electrical current passed through the samples. The total charge passed, in coulombs, has been found to be related to the resistance of the specimen to chloride ion penetration [40]. 


\section{Experimental Results and Discussion}

\subsection{CCP Synthesis}

CCP was synthesized using EDC and HCA with chitosan, as previously reported (Figure 2) [35,41]. First, chitosan $(500 \mathrm{mg})$ was dissolved in a $5 \mathrm{~N} \mathrm{HCl}$ solution $(2.5 \mathrm{~mL})$ and DDW (23 mL). Then, HCA $(590 \mathrm{mg})$ in ethanol $(2.5 \mathrm{~mL})$ and EDC $(625 \mathrm{mg})$ in ethanol $(10 \mathrm{~mL})$ were slowly added to the chitosan solution. The $\mathrm{pH}$ of the resultant solution was adjusted to 5.0 by using a saturated $\mathrm{NaOH}$ solution, and the reaction mixture was stirred at room temperature for $12 \mathrm{~h}$. Next, the $\mathrm{pH}$ of the mixture was again adjusted to 5.0 using the $5 \mathrm{~N} \mathrm{HCl}$ solution. The residue was dialyzed using a membrane against a $10 \mathrm{mM} \mathrm{NaCl}$ solution for two days and DDW for $24 \mathrm{~h}$, with a change of dialysate every $6 \mathrm{~h}$. Finally, the solution was frozen at $-20^{\circ} \mathrm{C}$ in a refrigerator and lyophilized.

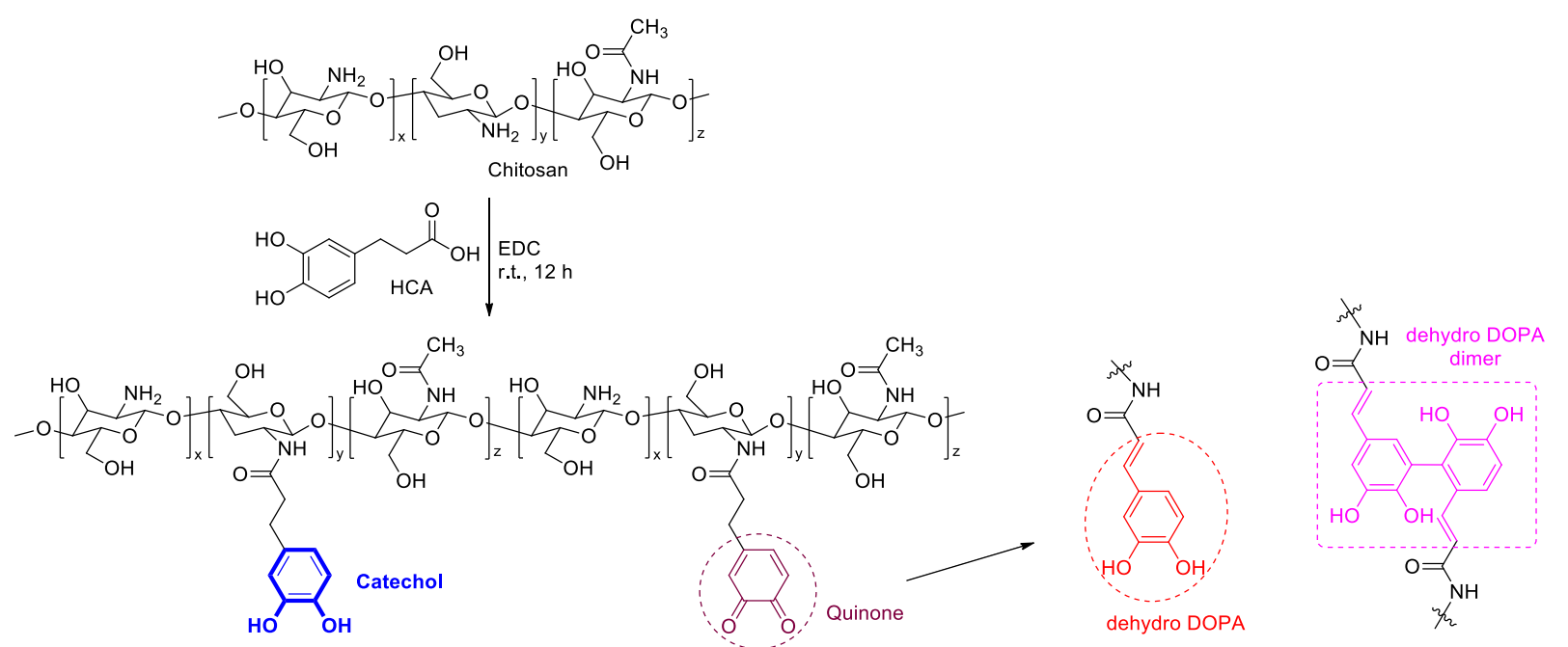

Figure 2. Synthesis of Cat-Chit and possible cross-linking pathways of catechol.

In addition, the absorbance of the Cat-Chit solution in DDW was analyzed by using a Genesys 180 ultraviolet-visible (UV-vis) spectrophotometer (Thermo Fisher, Waltham, MA, USA). Moreover, in order to conduct nuclear magnetic resonance (NMR) spectroscopy, Cat-Chit was dissolved in $\mathrm{D}_{2} \mathrm{O}$. Then, ${ }^{1} \mathrm{H}-\mathrm{NMR}$ spectra were recorded using a $500 \mathrm{MHz}$ NMR spectrometer (JEOL).

In order to investigate the interaction of Cat-Chit with a basic adduct from cement mortar, $40 \mathrm{mg}$ of Cat-Chit reacted with a $\mathrm{Ca}(\mathrm{OH})_{2}$ solution $(296 \mathrm{mg} / 40 \mathrm{~mL}$; this corresponds to a $0.1 \mathrm{M}$ concentration, which creates a similar environment to the adducts that form in cement mortar) at room temperature for $12 \mathrm{~h}$, after which the solid residue was washed with water and lyophilized, yielding a brown solid. The interaction between calcium and CCP was analyzed by Fourier transform infrared (FT-IR) spectroscopy using this solid. A mid-infrared (400-4000 $\mathrm{cm}^{-1}$ ) range Nicolet iS5 FT-IR Spectrometer (Thermo Scientific, Waltham, MA, USA) was used to collect spectra in the transmittance band between 400 and $4000 \mathrm{~cm}^{-1}$ at a resolution of $1 \mathrm{~cm}^{-1}$. In addition, scanning electron microscopy (SEM) images were recorded using an AIS1800C (SERON Technologies, Seoul, Korea).

\subsection{CCP Characterization}

The catechol group of the CCP was confirmed by UV-vis and ${ }^{1} \mathrm{H}$ NMR spectroscopies (Figure 3b,c). The UV-vis spectra revealed a maximum absorption peak of $280 \mathrm{~nm}$, which corresponded to the catechol conjugation; in addition, aromatic protons of catechol were represented at approximately $6.87 \mathrm{ppm}$ in the ${ }^{1} \mathrm{H}$ NMR spectra. Remarkably, the CCP was partially oxidized to quinone from catechol, as catechol is prone to oxidation. This quinone, a well-known and highly reactive species, was converted to 3,4-dihydroxyphenylalanine (dehydro-DOPA) moieties or dehydro-DOPA dimers (Figure 2) [42-44]. The UV-vis spectra 
of the synthesized CCP revealed a peak at approximately $330 \mathrm{~nm}$ and a broad peak at $350 \mathrm{~nm}$, which corresponded to the dehydro-DOPA [44] and the dehydro-DOPA dimer [45], respectively. Additionally, although catechol showed one multiple-type peak, quinone exhibited two peaks between 6.5 and 7.0 ppm (Figure 3c, blue circle). A weak, broad peak at approximately $2.5 \mathrm{ppm}$ was attributed to the methylene protons of HCA, whereas the protons of quinone appeared as two separate weak peaks (Figure 3c, red circle). Changes in the structure of the synthesized CCP were reflected by the light brown color of the product (Figure 3a), and the decrease in the solubility relative to that of Cat-Chit was observed.

(a)

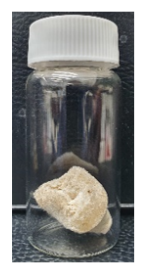

(b)

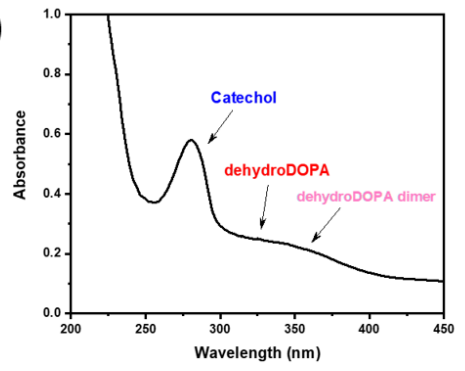

(c)

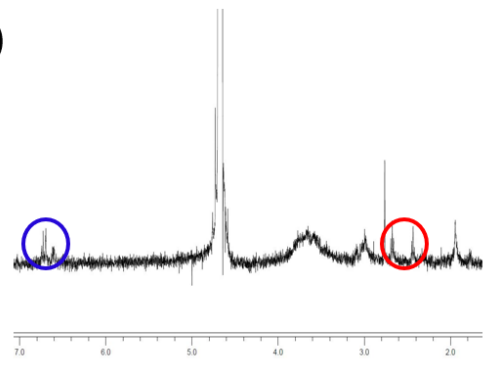

Figure 3. Qualitative analysis of Cat-Chit: (a) photograph of the product; (b) UV-vis spectrum; (c) ${ }^{1} \mathrm{H}-\mathrm{NMR}$.

In order to understand the interaction mechanism of the CCP with cement mortar, changes in the functional groups of the CCP were compared by using FT-IR before and after allowing the $\mathrm{CCP}$ to react with $\mathrm{Ca}(\mathrm{OH})_{2}$ (Figure 4). Before the reaction, the peak at approximately $3444 \mathrm{~cm}^{-1}$ corresponded to the hydroxy and amino groups in the CCP, and another peak at approximately $1633 \mathrm{~cm}^{-1}$ corresponded to carbonyl of amide (Figure 4 (black line)). In contrast, after treating $\mathrm{CCP}$ with $\mathrm{Ca}(\mathrm{OH})_{2}$, the absorption peak at approximately $3444 \mathrm{~cm}^{-1}$ was considerably attenuated because of the reaction with hydroxy and hydroxide, but significant new peaks appeared at 872 and $710 \mathrm{~cm}^{-1}$, representing the $\mathrm{Ca}-\mathrm{O}$ bonds (Figure 4 (red line)). This observation strongly suggests that an interaction occurred between $\mathrm{CCP}$ and $\mathrm{Ca}(\mathrm{OH})_{2}$, such as a cross-linking or chelation process.

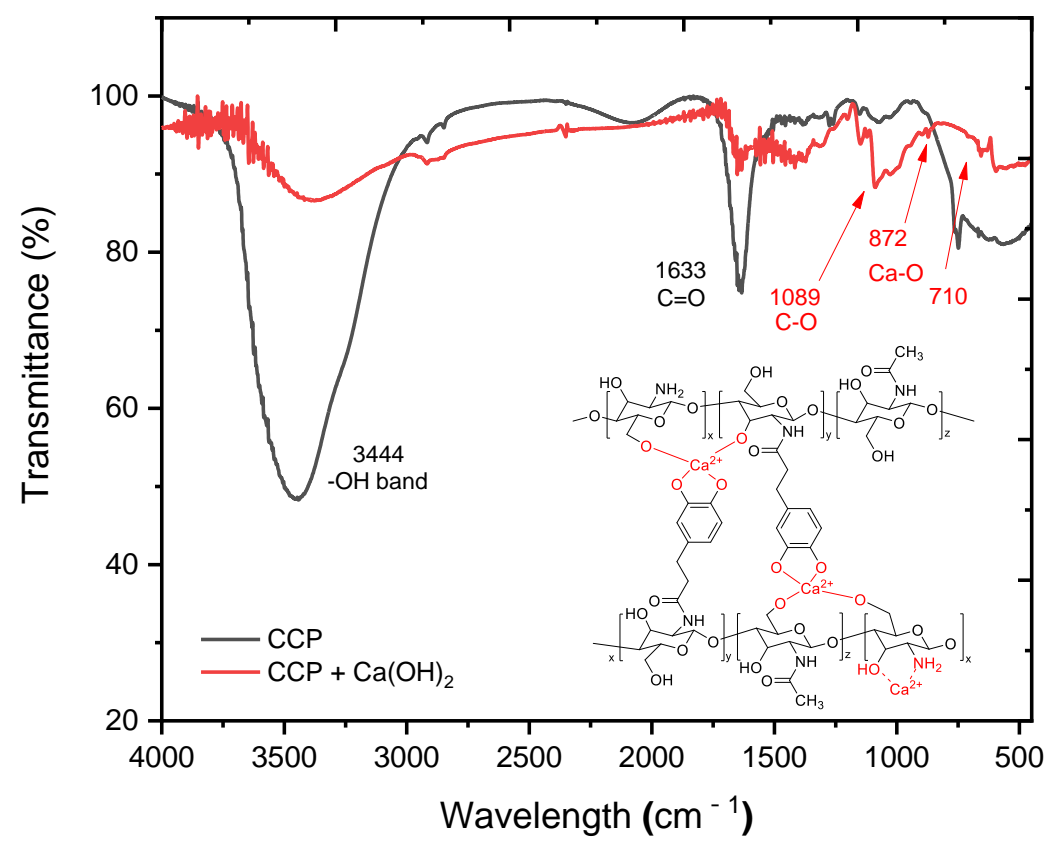

Figure 4. FT-IR spectra of CCP (black line) and CCP upon reacting with $\mathrm{Ca}(\mathrm{OH})_{2}$ (red line). The expected structure of calcium-Cat-Chit was added in the spectra. 
The SEM images in Figure 5a,b reveal the morphology of the CCP and calcium-CCP, respectively. In contrast to the transparent, smooth surface of the $\mathrm{CCP}$, the calcium cations in calcium-CCP were clearly detected in the form of spherical mineral deposits, and the rest of the surface appeared strong and rigid.

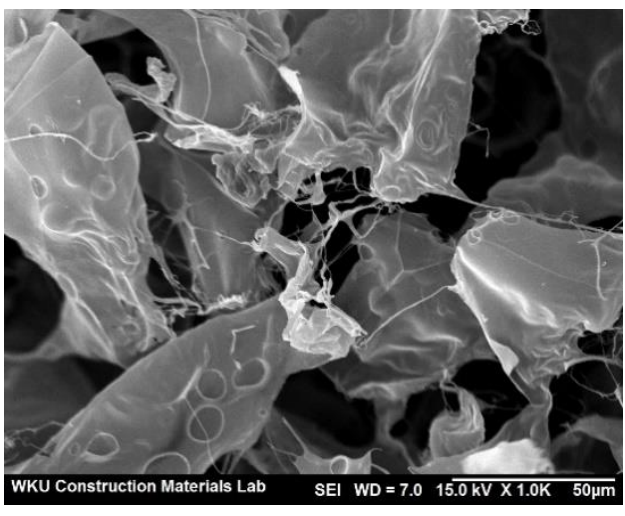

(a)

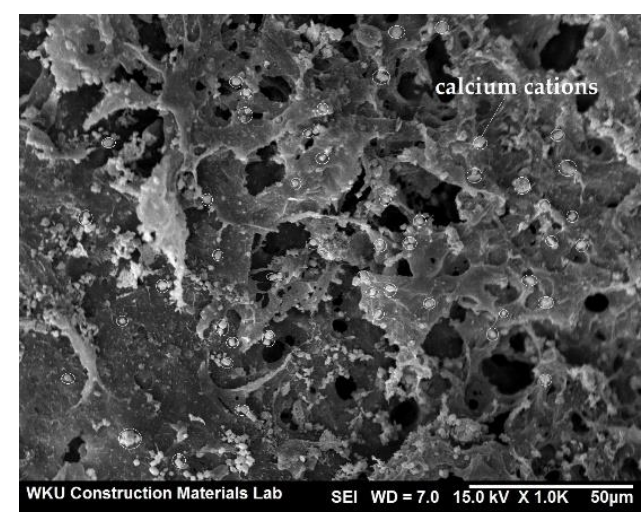

(b)

Figure 5. SEM images showing the morphology of (a) CCP and (b) calcium-CCP.

\subsection{Mortar Flow}

Figure 6 shows the variations in the flow of mortars with various amounts of CPW. Evidently, the mortar flow of the control mix was the highest at approximately $186 \mathrm{~mm}$, whereas those of the mixtures mixed with CPW were all slightly lower in the range of approximately 173-181 $\mathrm{mm}$. However, these differences in the flow were not significant, implying that the incorporation of the CCP did not significantly degrade the fluidity of the cement mortar.

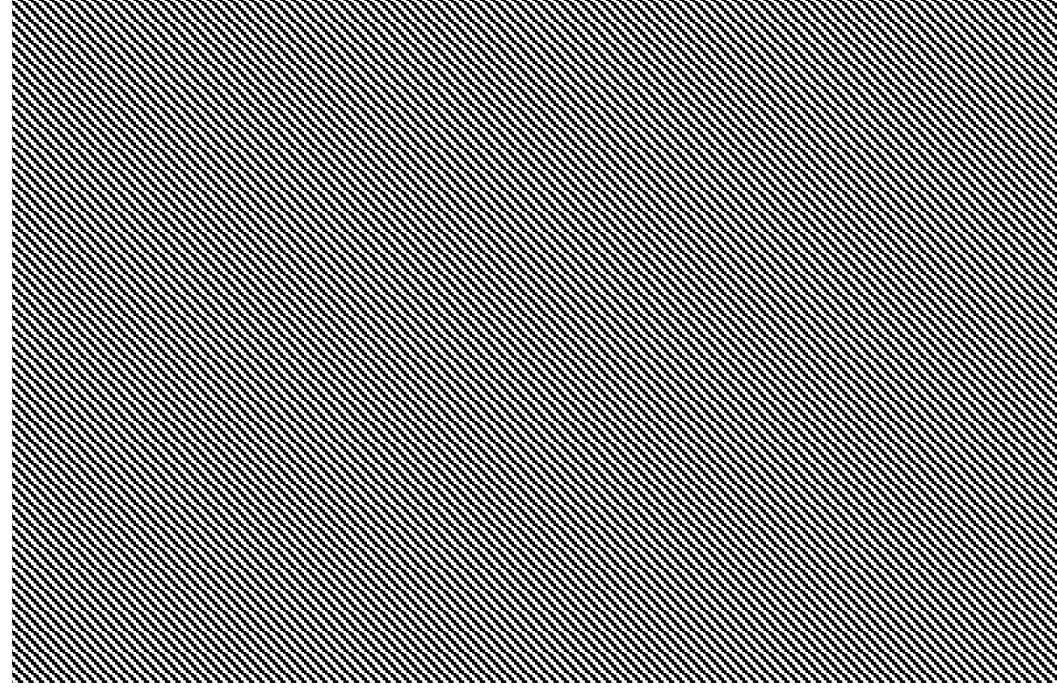

Figure 6. Mortar flow of the samples.

\subsection{Compressive Strength}

Figure 7 shows the changes in the compressive strengths of the mortars with various amounts of CPW after 7 and 28 days. After 7 days, the compressive strength of the control sample with no CPW was found to be approximately 39.4 MPa. By contrast, the 7-day compressive strength of the CPW7.5 sample was approximately $41.0 \mathrm{MPa}$, which was higher than that of other mixes and approximately $4 \%$ higher than that of the control sample. 


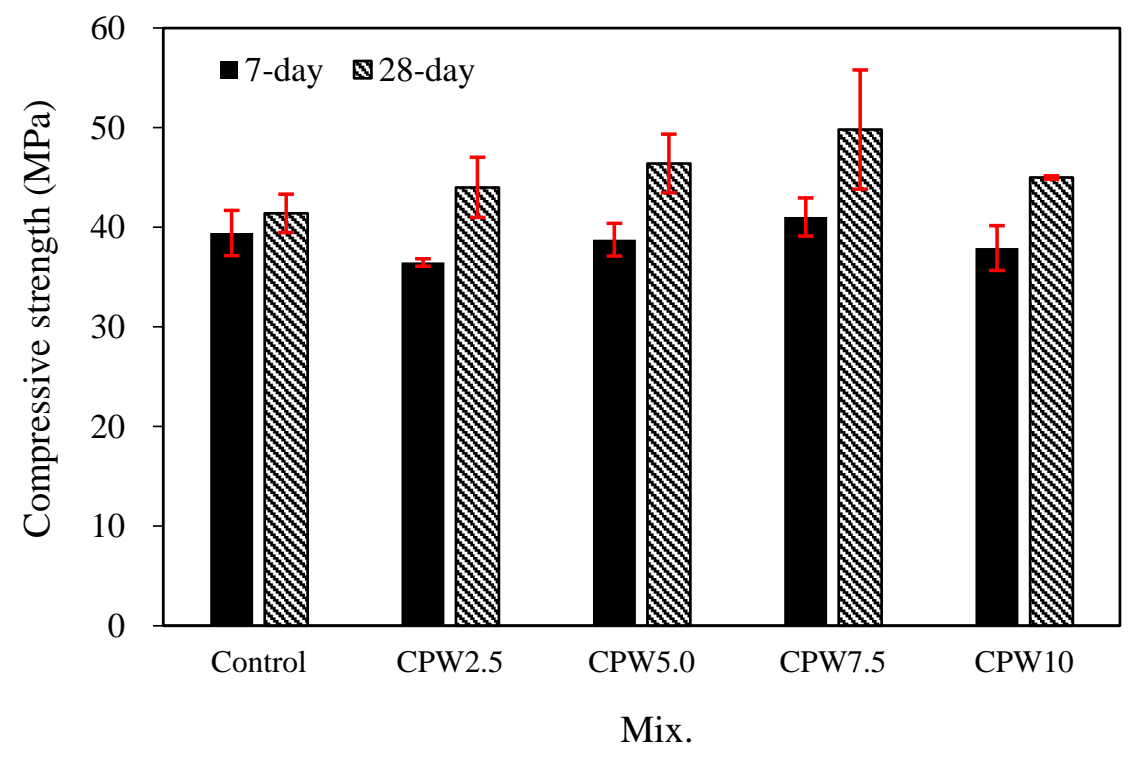

Figure 7. Compressive strength of the samples after 7 and 28 days.

This trend was more pronounced after 28 days. Specifically, while the 28-day compressive strength of the control sample was approximately $41.4 \mathrm{MPa}$, those of all the CPW samples were in the range of 44.0-49.8 MPa, indicating that they all had relatively higher compressive strengths than the control sample. In particular, the CPW7.5 sample again exhibited the highest compressive strength, viz., $49.8 \mathrm{MPa}$ after 28 days, which is approximately $20.2 \%$ higher than that of the control sample.

According to previous investigations [46-48] and our own study of the interaction mechanism, hydroxyl or amino groups of the CCP seem to participate in cross-linking or chelation reactions under certain basic conditions, such as the presence of $\mathrm{Ca}(\mathrm{OH})_{2}$ solution. These processes could be promoted to make the polymer more rigid through interactions among many functional groups in a high-concentration polymer solution. Indeed, the experimental results showed that the system with calcium-CCP cross-linking or chelating complexes had a higher compressive strength than the control system with no CPW.

Figure 8a,b show SEM images of the control sample and CPW7.5, respectively, after the 28-day compressive strength test. As shown in the figure, the surface of the CPW7.5 particles appears to be denser than that of the control sample.

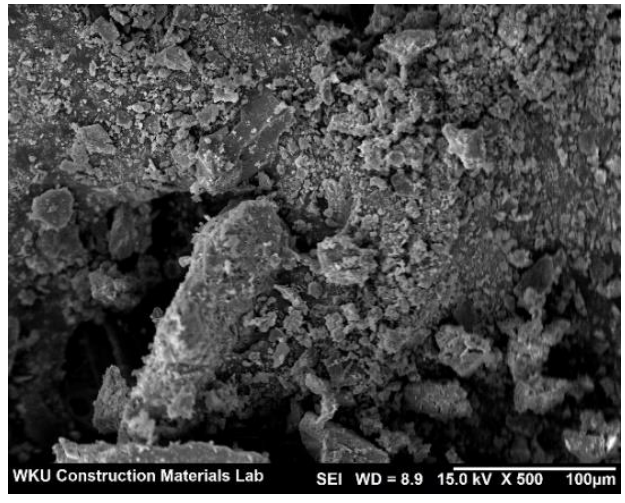

(a)

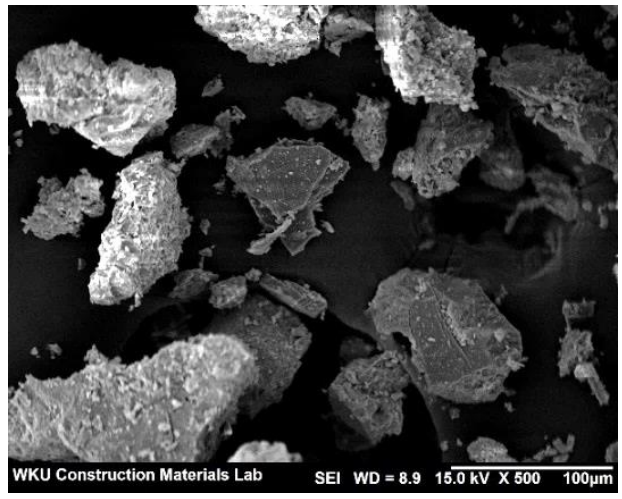

(b)

Figure 8. SEM images of the (a) control and (b) CPW7.5 samples.

In addition, in the samples containing $2.5-7.5 \%$ of $\mathrm{CPW}$, the compressive strength increased with increasing CPW proportion, but in the CPW10 sample, the compressive strength decreased relative to that of the CPW7.5 sample. This degradation was probably caused by self-aggregation [49], which generally occurs at higher polymer concentrations 
and is expected to decrease compressive strength. Therefore, mixing an appropriate amount of CCP with cement mortar was found to effectively improve the mechanical properties of the cement mortar.

\subsection{Tensile Strength}

Figure 9 shows the 28-day tensile strength of the mortar according to the amount of CPW. Evidently, the tensile strength of the mortar tends to increase as the CPW ratio increases. Specifically, the tensile strength of the samples containing $5 \%$ or more CPW (i.e., CPW5.0, CPW7.5, and CPW10) was approximately 3.97-4.39 MPa, which was $\sim 2.3-11.5 \%$ higher than that of the control sample. In addition, the tensile strength of CPW10 sample was higher than that of the CPW7.5 sample, indicating that the use of more CCP effectively increased the tensile strength of mortar. Therefore, the incorporation of CCP improves both the tensile and compressive strength of the mortar. In addition, the ratio of the tensile strength $(\mathrm{ft})$ to compressive strength $\left(\mathrm{fc}_{\mathrm{c}}\right)$ was approximately $8.0-9.8 \%$, which was similar regardless of the amount of CPW.

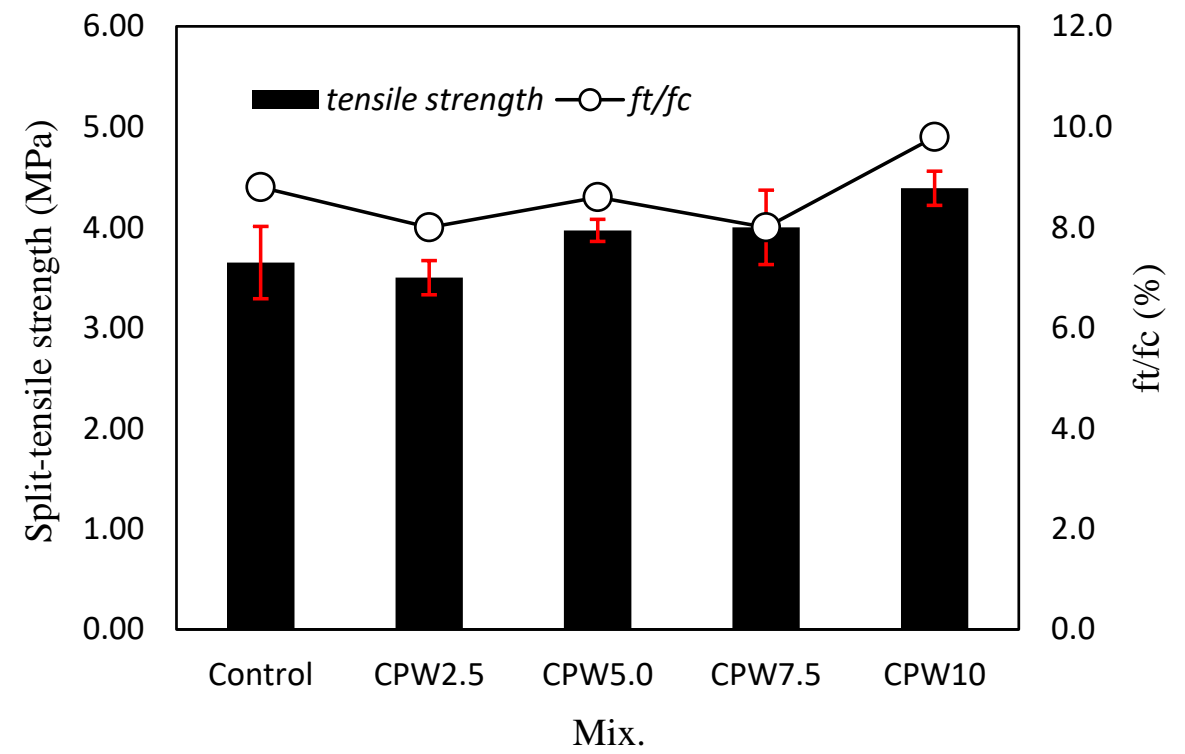

Figure 9. Tensile strength (left axis) and ratio of the tensile strength to compressive strength (right axis) of various mixed samples.

\subsection{Drying Shrinkage}

Figure 10 shows the change in the drying shrinkage of mortar after 56 days according to the amount of CPW. The drying shrinkages of the control sample and CPW2.5 were approximately $0.125-0.126 \%$ after 56 days, whereas those of CPW7.5 and CPW10 were also similar ( 0.131-0.133\%). However, the drying shrinkage of CPW5.0 was approximately $0.139 \%$, which was $\sim 11 \%$ higher than that of the control sample. In general, various factors affect the drying shrinkage of the mortar and concrete. In this study, the drying shrinkage of CPW5.0 was relatively large, but it is not clear whether this difference could be attributed to the presence of CCP or any other influencing factors. More detailed studies on shrinkage, including drying shrinkage and autogenous shrinkage of cement composites by the CCP proportion, are thus required. 


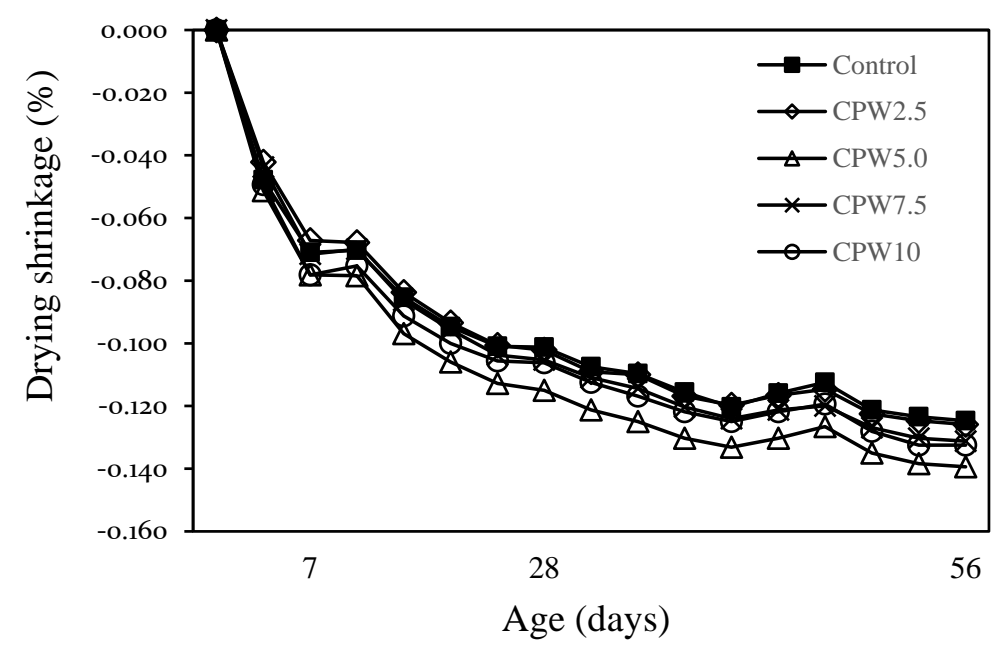

Figure 10. Drying shrinkage of samples.

\subsection{Accelerated Carbonation Depth}

Figure 11 shows the carbonation depth after 28 days of accelerated aging of the various samples. The carbonation depth of the control sample was approximately $1.36 \mathrm{~mm}$, which was higher than those of all the mixes containing CCP. In the case of samples containing $0-7.5 \% \mathrm{CCP}$, carbonation depth decreased as the CPW proportion increased. Particularly, the carbonation depth of CPW7.5 was approximately $1.14 \mathrm{~mm}$, which was about $16 \%$ lower than that of the control sample and the lowest among all the samples. Therefore, the proper incorporation of CCP effectively improves not only mechanical properties, such as the compressive and tensile strength (Figures 8 and 9, respectively), but also carbonation resistance. Taken together, these findings suggest that adding CPW makes the cement composites denser, which is known to increase compressive strength and decrease carbonation depth.

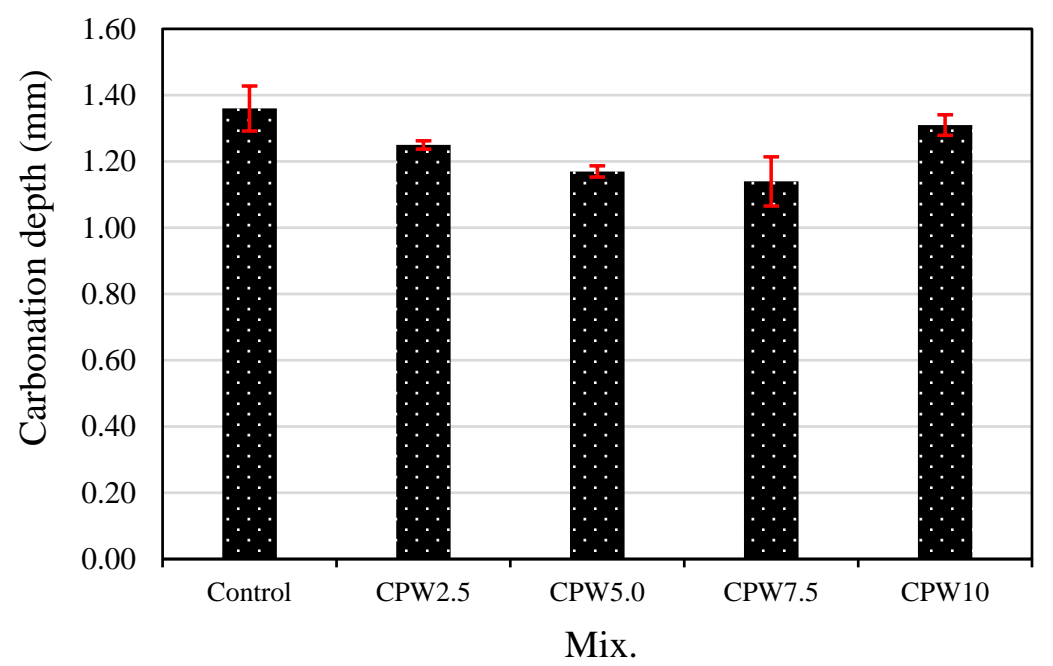

Figure 11. Accelerated carbonation depth of the samples.

\subsection{Chloride-Ion Penetrability}

As shown in Figure 12, which illustrates the chloride-ion penetrability according to the amount of $\mathrm{CPW}$, the total charge passing through the control mixture was the highest at approximately 10929 C. For the CPW2.5 sample, this value was slightly lower, and it continued to decrease with an increasing amount of CPW up to CPW7.5, which had a similar value to CPW10, (9744 and 9771 C, respectively). Therefore, the use of CCP is expected to improve the resistance of cement mortar relative to chloride-ion penetration. 


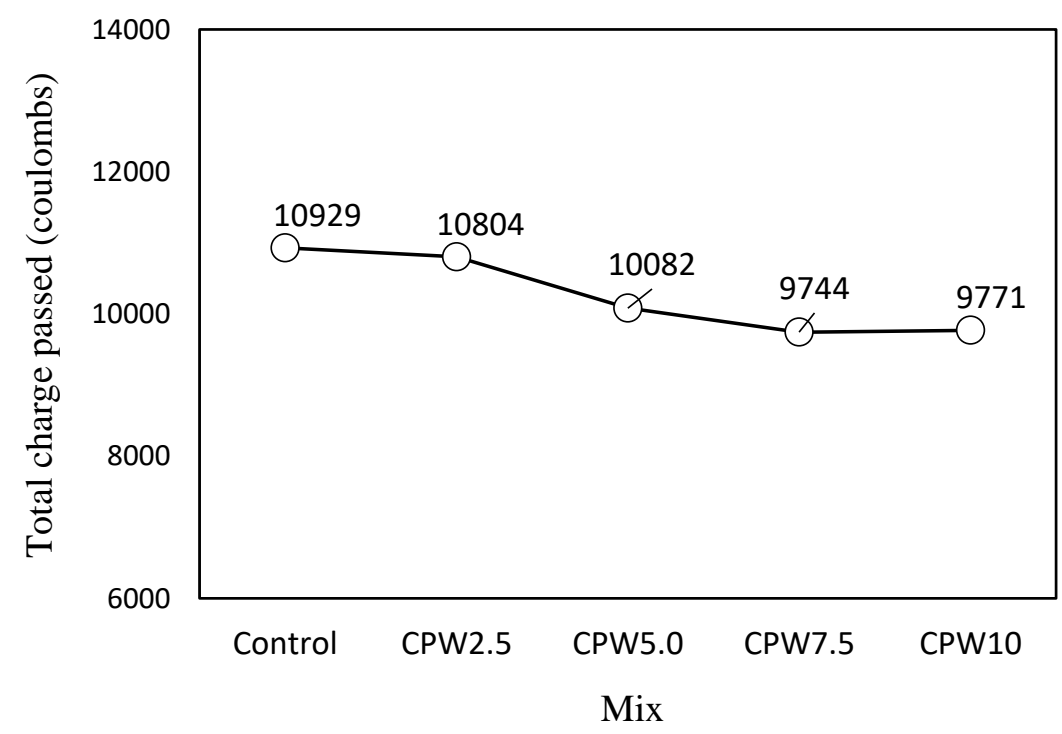

Figure 12. Chloride-ion penetrability of the samples after 28 days.

\section{Conclusions}

This paper describes the first application of CCP to cement mortar in order to improve its mechanical properties and durability. The following conclusions can be derived from this study.

The results showed that an interaction between the synthesized polymer and $\mathrm{Ca}(\mathrm{OH})_{2}$ made CCP compatible with cement mortars.

The flow of samples with and without the CCP was not significantly different, implying that the incorporation of the CCP did not significantly affect the fluidity of the cement mortar.

The CPW7.5 sample exhibited the highest 7-day and 28-day compressive strength. Specifically, after 28 days, its compressive strength was $49.8 \mathrm{MPa}$, which was approximately 20.2\% higher than that of the control sample. The tensile strength of the CPW5.0, CPW7.5, and CPW10 samples was approximately 3.97-4.39 $\mathrm{MPa}$, which was $\sim 2.3-11.5 \%$ higher than that of the control sample.

The carbonation depth of CPW7.5 was approximately $1.14 \mathrm{~mm}$, which was about $16 \%$ lower than that of the control sample. Therefore, the proper incorporation of CCP effectively improves not only mechanical properties but also carbonation resistance.

The total charge passing through the samples decreased as the amount of CPW increased. Therefore, CCP is concluded to improve chloride ion penetration resistance of cement mortar.

Further studies are required in order to establish how the presence of CCP affects viscosity, shrinkage, and long-term mechanical strength, as well as how CCP influences the relationship between the microstructures of cement composites and their mechanical properties and durability characteristics.

Author Contributions: Conceptualization, S.-J.C. and H.-M.K.; investigation, S.-J.C., S.-H.B., J.-I.L. and E.-J.B.; data Curation, J.-I.L. and E.-J.B.; writing-original draft preparation, S.-J.C. and H.-M.K.; writing-review and editing, S.-J.C. and S.-H.B. All authors have read and agreed to the published version of the manuscript.

Funding: This work was supported by a National Research Foundation of Korea (NRF) grant funded by the Korean government (MSIT) (No. 2020R1A4A3079595). This research was also supported by the Basic Science Research Program through the NRF funded by the Ministry of Education (NRF-2019R1I1A3A01049510, NRF-2018R1D1A1B07042179).

Institutional Review Board Statement: Not applicable.

Informed Consent Statement: Not applicable.

Data Availability Statement: Not applicable. 
Acknowledgments: The authors gratefully acknowledge National Research Foundation of Korea (NRF) for the financial support of this work.

Conflicts of Interest: The authors declare no conflict of interest.

\section{References}

1. Jang, I.; Son, D.; Ryu, Y.; Park, W.; Yi, C. Strength and healing performance of the mortar using bacterial pellet as a self-healing material. J. Rec. Const. Res. 2020, 8, 112-119.

2. Luo, M.; Qian, C.X.; Li, R.-Y. Factors affecting crack repairing capacity of bacteria-based self-healing concrete. Constr. Build. Mater. 2015, 87, 1-7. [CrossRef]

3. Alghamri, R.; Kanellopoilos, A.; Al-Tabbaa, A. Impregnation and encapsulation of lightweight aggregates for self-healing concrete. Constr. Build. Mater. 2016, 124, 910-921. [CrossRef]

4. Souradeep, G.; Kua, H.W. Encapsulation technology and techniques in self-healing concrete. J. Mater. Civ. Eng. 2016, 28, 04016165. [CrossRef]

5. Vijay, K.; Murmu, M.; Deo, S.V. Bacteria based self-healing concrete-a review. Constr. Build. Mater. 2017, 152, 1008-1014. [CrossRef]

6. Sik, W.H.; Sun, P.B.; Won, Y.S.; Chel, C.Y. Crack self-healing performance according to absorption test of fiber-reinforced concrete. J. Korea Inst. Struct. Maint. Insp. 2019, 23, 122-129.

7. Bezerra, U.T.; Ferreira, R.M.; Castro-Gomes, J.P. The effect of latex and chitosan biopolymer on concrete properties and performance. Key Eng. Mater. 2011, 466, 37-46.

8. Kumar, R. A review on epoxy and polyester based polymer concrete and exploration of polyfurfuryl alcohol as polymer concrete. J. Polym. 2016, 2016, 7249743. [CrossRef]

9. Novoa, P.J.R.O.; Riveiro, M.C.S.; Ferreira, A.J.M.; Marques, A.T. Mechanical characterization of lightweight polymer mortar modified with cork granulates. Compos. Sci. Technol. 2004, 64, 2197-2205. [CrossRef]

10. Choi, S.; Hong, B.; Lee, S.; Won, J. Shrinkage and corrosion resistance of amorphous metallic-fiber-reinforced cement composites. Compos. Struct. 2014, 107, 537-543. [CrossRef]

11. Cho, B.; Park, S.; Park, J. Mechanical properties of polymer concrete made with recycled PET and recycled concrete aggregates. Constr. Build. Mater. 2008, 22, 2281-2291.

12. Ferdous, W.; Manalo, A.; Wong, H.S.; Abousnina, R.; Ajarmeh, O.S.A.I.; Zhuge, Y.; Schubel, P. Optimal design for epoxy polymer concrete based on mechanical properties and durability aspects. Constr. Build. Mater. 2020, 232, 117229. [CrossRef]

13. Azadmanesh, H.; Hashemi, S.A.H.; Ghasemi, S.H. The effect of styrene-butadiene rubber and ethylene vinyl acetate polymers on the mechanical properties of Engineered Cementitious Composites. Compos. Commun. 2021, 24, 100656. [CrossRef]

14. Mohesson, H.M.; Abbas, W.A. Effect of biopolymer alginate on some properties of concrete. J. Eng. 2020, 26, 121-131. [CrossRef]

15. Shanmugavel, D.; Selvaraj, T.; Ramadoss, R.; Raneric, S. Interaction of a viscous biopolymer from cactus extract with cement paste to produce sustainable concrete. Constr. Build. Mater. 2020, 257, 119585. [CrossRef]

16. Snoeck, D.; Moerkerke, B.; Mignon, A.; De Belie, N. In-situ crosslinking of superabsorbent polymers as external curing layer compared to internal curing to mitigate plastic shrinkage. Constr. Build. Mater. 2020, 262, 120819. [CrossRef]

17. Mignon, A.; Vermeulen, J.; Snoeck, D.; Dubruel, P.; Van Vlierberghe, S.; De Belie, N. Mechanical and Self-healing properties of cementitious materials with $\mathrm{pH}$-responsive semi-synthetic superabsorbent polymers. Mater. Struct. 2017, 50, 238. [CrossRef]

18. Mignon, A.; Snoeck, D.; D’Halluin, K.; Balcaen, L.; Vanhaecke, F.; Dubruel, P.; Van Vlierberghe, S.; De Belie, N. Alginate biopolymers: Counteracting the impact of superabsorbent polymers on mortar strength. Constr. Build. Mater. 2016, 110, 169. [CrossRef]

19. Wang, J.; Mignon, A.; Snoeck, D.; Wiktor, V.; Boon, N.; De Belie, N. Application of modified-alginate encapsulated carbonate producing bacteria in concrete: A promising strategy for crack self-healing. Front. Microbiol. 2015, 6, 1088. [CrossRef]

20. Ryu, J.H.; Lee, Y.; Kong, W.H.; Kim, T.G.; Park, T.G.; Lee, H. Catechol-functionalized chitosan/pluronic hydrogels for tissue adhesives and hemostatic materials. Biomacromolecules 2011, 12, 2653-2659. [CrossRef]

21. Xu, J.; Strandman, S.; Zhu, J.X.X.; Barralet, J.; Cerruti, M. Genipin-crosslinked catechol-chitosan mucoadhesive hydrogels for buccal drug delivery. Biomaterials 2015, 37, 395-404. [CrossRef]

22. Kean, T.; Thanou, M. Biodegradation, biodistribution and toxicity of chitosan. Adv. Drug Deliv. Rev. 2010, 62, 3-11. [CrossRef] [PubMed]

23. Dufes, C.; Muller, J.M.; Couet, W.; Olivier, J.C.; Uchegbu, I.F.; Schatzlein, A.G. Anticancer drug delivery with transferrin targeted polymeric chitosan vesicles. Pharm. Res. 2004, 21, 101-107. [CrossRef]

24. Zaharoff, D.A.; Rogers, C.J.; Hance, K.W.; Schlom, J.; Greiner, J.W. Chitosan solution enhances both humoral and cell-mediated immune responses to subcutaneous vaccination. Vaccine 2007, 25, 2085-2094. [CrossRef] [PubMed]

25. Bajaj, G.; Van Alstine, W.G.; Yeo, Y. Zwitterionic chitosan derivative, a new biocompatible pharmaceutical excipient, prevents endotoxin-mediated cytokine release. PLoS ONE 2012, 7, e30899. [CrossRef]

26. Li, P.; Poon, Y.F.; Li, W.; Zhu, H.Y.; Yeap, S.H.; Cao, Y.; Qi, X.; Zhou, C.; Lamrani, M.; Beuerman, R.W.; et al. A polycationic antimicrobial and biocompatible hydrogel with microbe membrane suctioning ability. Nat. Mater. 2011, 10, 149-156. [CrossRef] [PubMed] 
27. Yang, S.H.; Lee, Y.S.; Lin, F.H.; Yang, J.M.; Chen, K.S. Chitosan/poly(vinyl alcohol) blending hydrogel coating improves the surface characteristics of segmented polyurethane urethral catheters. J. Biomed. Mater. Res. B Appl. Biomater. 2007, 83, $304-313$. [CrossRef]

28. Rabea, E.I.; Badawy, M.E.; Stevens, C.V.; Smagghe, G.; Steurbaut, W. Chitosan as antimicrobial agent: Applications and mode of action. Biomacromolecules 2003, 4, 1457-1465. [CrossRef]

29. Kim, K.; Ryu, J.H.; Lee, D.Y.; Lee, H. Bio-inspired catechol conjugation converts water-insoluble chitosan into a highly watersoluble, adhesive chitosan derivative for hydrogels and LbL assembly. Biomater. Sci. 2013, 1, 783-790. [CrossRef]

30. Kim, K.; Kim, K.; Ryu, J.H.; Lee, H. Chitosan-catechol: A polymer with long-lasting mucoadhesive properties. Biomaterials 2015, 52, 161-170. [CrossRef]

31. Shin, M.; Park, S.-G.; Oh, B.-C.; Kim, K.; Jo, S.; Lee, M.S.; Oh, S.S.; Hong, S.-H.; Shin, E.-C.; Kim, K.-S.; et al. Complete prevention of blood loss with self-sealing haemostatic needles. Nat. Mater. 2017, 16, 147-152. [CrossRef] [PubMed]

32. Chen, W.; Shen, X.; Hu, Y.; Xu, K.; Ran, Q.; Yu, Y.; Dai, L.; Yuan, Z.; Huang, L.; Shen, T.; et al. Surface functionalization of titanium implants with chitosan-catechol conjugate for suppression of ROS-induced cells damage and improvement of osteogenesis. Biomaterials 2017, 114, 82-96. [CrossRef]

33. Xu, J.; Soliman, G.M.; Barralet, J.; Cerruti, M. Mollusk glue inspired mucoadhesives for biomedical applications. Langmuir 2012, 28, 14010-14017. [CrossRef] [PubMed]

34. Huang, X.; Bao, X.; Liu, Y.; Wang, Z.; Hu, Q. Catechol/functional chitosan/silver nanoparticle composite as a highly effective antibacterial agent with species-specific mechanisms. Sci. Rep. 2017, 7, 1860. [CrossRef] [PubMed]

35. Ryu, J.H.; Choi, J.S.; Park, E.S.; Eom, M.R.; Jo, S.G.; Lee, M.S.; Kwon, S.K. Chitosan oral patches inspired by mussel adhesion. J. Control Release 2020, 317, 57-66. [CrossRef] [PubMed]

36. KS L 5105. Testing Method for Compressive Strength of Hydraulic Cement Mortars, Korea Industrial Standards; Korean Standards \& Certification Information Center: Seoul, Korea, 2007.

37. KS F 2423. Standards Test Method for Tensile Splitting Strength of Concrete. Korea Industrial Standards; Korean Standards \& F 2423. Standards \& Certification Information Center: Seoul, Korea, 2016.

38. KS F 2424. Standard Test Method for Length Change of Mortar and Concrete, Korea Industrial Standards; Korean Standards \& Certification Information Center: Seoul, Korea, 2015.

39. KS F 2584. Standard Test Method for Accelerated Carbonation of Concrete, Korea Industrial Standards; Korean Standards \& Certification Information Center: Seoul, Korea, 2015.

40. ASTM C 1202. Standard Test Method for Electrical Indication of Concrete's Ability to Resist Chloride Ion Penetration; American Society for Testing and Materials, ASTM International: West Conshohocken, PA, USA, 2019.

41. Narkar, A.R.; Cannon, E.; Yildirim-Alicea, H.; Ahn, K. Catechol-functionalized chitosan: Optimized preparation method and its interaction with Mucin. Langmuir 2019, 35, 16013-16023. [CrossRef]

42. Ahn, B.K. Perspectives on mussel-inspired wet adhesion. J. Am. Chem. Soc. 2017, 139, 10166-10171. [CrossRef]

43. Yang, J.; Stuart, M.A.C.; Kamperman, M. Jack of all trades: Versatile catechol crosslinking mechanisms. Chem. Soc. Rev. 2014, 43, 8271-8298. [CrossRef]

44. Lee, B.P.; Dalsin, J.L.; Messersmith, P.B. Synthesis and gelation of DOPA-modified poly (ethylene glycol) hydrogels. Biomacromolecules 2002, 3, 1038-1047. [CrossRef]

45. Burzio, L.A.; Waite, J.H. Reactivity of peptidyl-tyrosine to hydroxylation and cross-linking. Protein Sci. 2001, 10, 735-740. [CrossRef]

46. Flores-Arriaga, J.C.; de Pozos-Guillén, A.J.; González-Ortega, O.; Escobar-García, D.M.; Masuoka-Ito, D.; del Campo-Téllez, B.I.M.; Cerda-Cristerna, B.I. Calcium sustained release, $\mathrm{pH}$ changes and cell viability induced by chitosan-based pastes for apexification. Odontology 2019, 107, 223-230. [CrossRef] [PubMed]

47. Bonapasta, A.A. Cross-linking of poly (vinyl alcohol) chains by Ca ions in macro-defect-free cements. Chem. Mater. 2002, 14, 1016-1022. [CrossRef]

48. Li, Z.; de Souza, L.R.; Litina, C.; Markaki, A.E.; Al-Tabba, A. Feasibility of using 3D printed polyvinyl alcohol (PVA) for creating self-healing vascular tunnels in cement systems. Materials 2019, 12, 3872. [CrossRef] [PubMed]

49. Hu, Y.; Du, Y.; Yang, J.; Tang, Y.; Li, J.; Wang, X. Self-aggregation and antibacterial activity of N-acylated chitosan. Polymer 2007, 48, 3098-3106. [CrossRef] 